\title{
FEATURE Branching out: Agroforestry as a climate change mitigation and adaptation tool for agriculture
}

\author{
Michele Schoeneberger, Gary Bentrup, Henry de Gooijer, Raju Soolanayakanahally, Tom Sauer,
} James Brandle, Xinhua Zhou, and Dean Current

\section{MEETING MULTIPLE DEMANDS UNDER CLIMATE CHANGE}

US and Canadian agricultural lands are being pressed to provide more environmental and economic services, while at the same time their capacity to provide these services under potential climate change (CC) is being questioned (Field et al. 2007; CAST 2011). Producers are already experiencing weather patterns outside of climate norms (e.g., the 2011 droughts in Texas, and flooding along the Missouri River in the United States and along the Red River in Canada) that have had significant impacts on production. Predictions of future climate conditions for the US Midwest include longer growing seasons that could potentially increase crop yields but also increase heat waves, floods, droughts, and insect and weed issues that may then adversely impact production (USGCRP 2009). Climate change drives many stressors and interacts with many nonclimatic stressors. This makes it difficult to forecast outcomes in any general way other than many existing threats to agricultural production, such as erosion and pests, which will most likely be exacerbated under shifting climate (Field et al. 2007; USGCRP 2009). Creating profitable and healthy operations under this unpredictable interplay of factors driven

Michele Schoeneberger is research leader and soil scientist and Gary Bentrup is research landscape planner with the US Forest Service, USDA National Agroforestry Center, Lincoln, Nebraska. Henry de Gooijer is unit manager and Raju Soolanayakanahally is senior agroforestry researcher with the Agroforestry Development Centre, Science and Technology Branch, Agriculture and Agri-Food Canada, Indian Head, Saskatchewan, Canada. Tom Sauer is research soil scientist with the USDA Agricultural Research Service National Laboratory for Agriculture and the Environment, Ames, lowa. James Brandle is professor of Shelterbelt Ecology, School of Natural Resources, University of Nebraska, Lincoln, Nebraska. Xinhua Zhou is statistician with the Department of Biostatistics, University of Kansas, Kansas City, Kansas. Dean Current is program director with the Center for Integrated Natural Resource and Agricultural Management, University of Minnesota, St. Paul, Minnesota. by shifting climate (and, along with it, shifting markets) will be a daunting task. It will be essential that farmers, ranchers, and even communities have a variety of land management options to minimize the risks and maximize services under such uncertain conditions.

A recent Council for Agricultural Science and Technology report (CAST 2011) discusses the need to adapt "management and land use to cope with the changes in climate and adopt mitigation strategies to decrease agriculture's net contributions to greenhouse gas (GHG) production." Delgado et al. (2011) have suggested that "these challenges can be met by maximizing soil and water conservation to develop sustainable systems essential to mitigate climate change and adapt to it.' The special section in this issue of the Journal of Soil and Water Conservation is a product culminating from several events organized by Jorge Delgado from the USDA Agricultural Research Service and his colleagues to catalyze discussion on this topic and to bring the science at-hand together so that we can begin assembling a CC-integrated conservation toolbox for North American agricultural lands (Delgado et al. 2011; SWCS 2011; SWCS 2012). Agroforestry, the intentional integration of trees and/or shrubs into crop and animal production systems, is one of these potential tools.

\section{A CLIMATE CHANGE INTEGRATED STRATEGY}

There are five main categories of agroforestry practices in North America, with a growing sixth category-Special Applications-for agroforestry technologies being adapted to address emerging needs across rural/urban landscapes, such as stormwater treatment and biofeedstock production (figure 1 and table 1). As a suite of practices to assist in creating productive and healthy farm and ranch operations, agroforestry has the potential to contribute to both CC mitigation and adaptation (M\&A) by sequestering carbon (C), reducing GHG emissions, enhanc- ing resiliency, and reducing threats while facilitating migration to more favorable conditions in the highly fragmented agricultural landscapes (table 2).

Although agroforestry's CC M\&A potential is better recognized in the tropics (Verchot et al. 2007), awareness of its potential for temperate and boreal systems is growing (Morgan et al. 2010; CAST 2011). Its use as a CC M\&A strategy on agricultural lands in North America is not a new idea. Indeed, the Prairie States Forestry Program in the United States and Prairie Farm Rehabilitation Administration in Canada may well serve as models for an effective CC M\&A project (Sauer 2010). To deal with one of the largest North American wind-erosion events - the 1930s Dust Bowl-both programs planted hundreds of millions of trees into windbreaks across the length of the North American Great Plains. Two things are worth noting here. This largescale ecological disaster was the outcome of an extreme and prolonged weather event in combination with a large-scale land-use intensification/conversion tied to fluctuating crop prices. In addition, use of the M\&A activity was retroactive, which generally results in longer recovery times and greater costs. To provide the services needed to combat weather extremes and other CC-driven impacts when they occur, agroforestry, like many other management options in the CC toolbox, needs to be implemented proactively. For trees, this means planting several years prior to an event. Therefore, these practices must also be able to offset lost opportunity costs in the meantime by providing non-CC M\&A services that producers value. This is part of agroforestry's appeal as a CC M\&A tool. The benefits (more favorable microclimates, enhanced biodiversity, reduced wind velocity, improved soil fertility, diversification of production, increased resource-use efficiency, reduced nutrient runoff, and decreased levels of erosion) from its incorporation are the very functions that can be capitalized for CC M\&A 


\section{Figure 1}

North American agroforestry is comprised of six different practices that take advantage of the interactive benefits from combining trees and shrubs with crops and/or livestock to create integrated and sustainable land-use systems. See table 1 for more information on agroforestry.

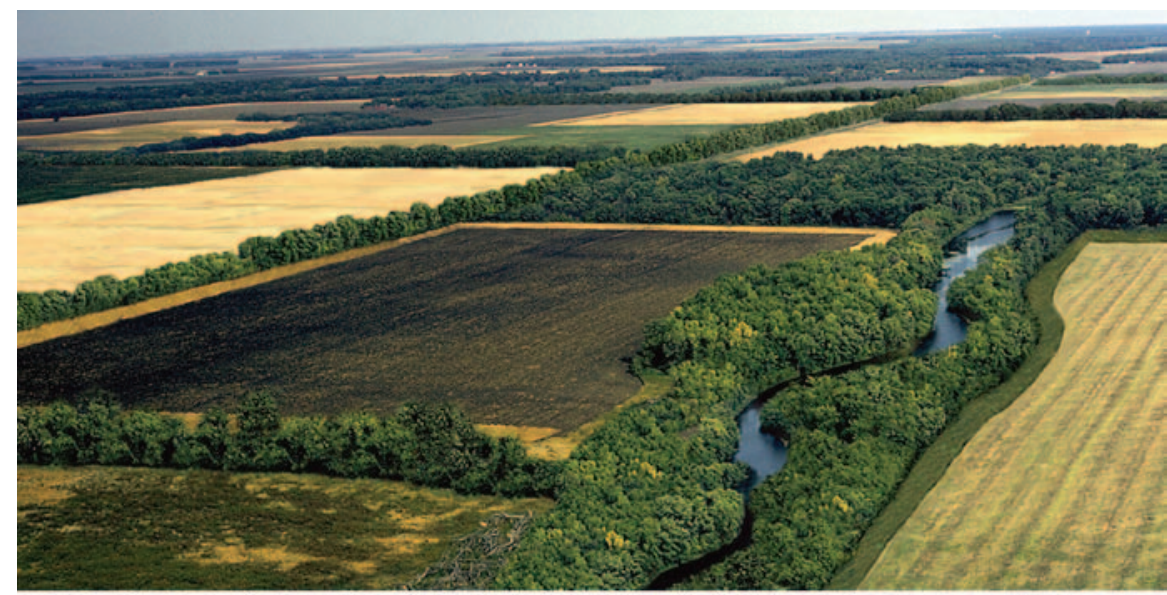

Riparian forest buffers are streamside plantings of trees, shrubs and grasses that reduce water pollution and bank erosion, protect aquatic environments, and enhance wildlife habitat.

Silvopasture systems combine trees with forage and livestock production on the same field. The trees are managed for wood while at the same time provide shade and shelter for livestock.

Forest farming is the cultivation of highvalue non-timber crops (food, medicinal, and crafts) under the protection of a forest canopy that has been managed to provide a favorable crop environment.
Windbreaks are rows of trees and shrubs that reduce wind speed. They improve crop yields, reduce soil erosion, improve water-efficiency, protect livestock and conserve energy.

Alley cropping systems are widelyspaced rows of high-value trees that create alleyways for crops. This system benefits trees and crops and provides annual and long term cash flow.

Special applications are plantings used to solve unique problems. Examples include the utilization of wastewater to produce a short rotation woody crop and plantings to help stabilize streambanks.

\section{Table 1}

Selected additional sources of North American agroforestry information and tools.

\section{Sources}

USDA Forest Service/Natural Resources Conservation Service National Agroforestry Center,

http://www.unl.edu/nac.

Agroforestry Development Centre: Agriculture and Agri-Food Canada, http://www.agr.gc.ca.

Association of Temperate Agroforestry, http://www.aftaweb.org.

Center for Integrated Natural Resource and Agriculture Management, http://www.cinram.umn.edu.

Centre for Northern Agroforestry \& Afforestation, http://www.saskagroforestry.ca.

Center for Agroforestry - University of Missouri, http://centerforagroforestry.org.

North American Agroforestry: An Integrated Science and Practice. 2009. By H.E. Garrett (ed).

Madison, WI: American Society of Agronomy, Inc.

Temperate Agroforestry Systems. 1997. By A.M. Gordon and S.M. Newman (ed). New York, NY: CAB International.

USDA COMET-VR 2 (Carbon Management Online Tool for Agriculture and Agroforestry V. 2), http://www.comet2.colostate.edu.

Agriculture and Agri-Food Canada HOLOS, ftp://ftp.agr.gc.ca/pub/outgoing/HOLOS. services (table 2 and figure 2) (Eagle et al. 2012; Tsonkova et al. 2012).

\section{GREENHOUSE GAS MITIGATION}

Carbon. Incorporation of agroforestry into conventional agricultural operations, regardless of purpose (figures 1 and 2), will result in new $\mathrm{C}$ being sequestered. This $\mathrm{C}$ can be substantial despite the small area of land required by agroforestry (e.g., approximately $3 \%$ of a field for crop windbreaks) due to the high rates of $\mathrm{C}$ sequestered per unit area (Schoeneberger 2009). Potential sequestration rates for above and belowground biomass components in riparian forest buffers, alley-cropping systems, silvopastures, and windbreaks in North America have been estimated at 2.6, 3.4, 6.1, and 6.4 Mg C ha $\mathrm{Mg}^{-1}(1.2,1.5$, 2.7 , and 2.8 tn $\left.\mathrm{C} \mathrm{ac}{ }^{-1} \mathrm{yr}^{-1}\right)$, respectively (Udawatta and Jose 2011). Agroforestry provides for greater $\mathrm{C}$ sequestration than through conventional options alone while leaving the bulk of the land in agricultural production. For example, a 13-year-old alley-cropping system in Ontario, Canada, was found to have $11 \%$ to $41 \%$ more C, depending on tree species, compared to sole-cropping plots (Peichl et al. 2006). These numbers, though, only represent a partial accounting as agroforestry impacts on overall $\mathrm{C}$ dynamics are many and complex. However, three main C components should be accounted for where possible: woody biomass, soil, and indirect benefits.

The woody biomass component represents the major portion of easily observed and measured new $\mathrm{C}$ to the system (Schoeneberger 2009). The bulk of this $\mathrm{C}$ is generally contained within the aboveground woody portion (trunk and branches). For example, aboveground woody biomass $\mathrm{C}$ in hybrid poplar (Populus deltoids X Populus nigra) and Norway spruce (Picea abies L.) comprised approximately $82 \%$ and $79 \%$, respectively, of the total woody biomass $\mathrm{C}$ in the 13-year-old alley cropping system mentioned earlier (Peichl et al. 2006). A similar trend of allocation was found for hybrid poplar in a 7-year-old multispecies riparian buffer in Iowa (Tufekcioglu et al. 2003). Unfortunately, accounting for even this $\mathrm{C}$ in agroforestry plantings, especially at regional and national scales, 


\section{Table 2}

While delivering other production and natural resource services to farmers, ranchers, and communities, agroforestry has the potential to address climate change mitigation and adaptation needs for agricultural lands.

\begin{tabular}{|c|c|c|}
\hline Climate change activity* & Major climate change functions & Agroforestry functions that support climate change mitigation and adaptation \\
\hline \multicolumn{3}{|l|}{ Mitigation } \\
\hline \multirow{10}{*}{$\begin{array}{l}\text { Activities that reduce GHGs in the } \\
\text { atmosphere or enhance the storage } \\
\text { of GHGs stored in ecosystems }\end{array}$} & Sequester carbon & Accumulate $\mathrm{C}$ in woody biomass \\
\hline & & Accumulate $\mathrm{C}$ in soil \\
\hline & Reduce GHG emissions & Reduce fossil fuel consumption: \\
\hline & & Reduce equipment runs in areas with trees \\
\hline & & Reduce farmstead heating and cooling \\
\hline & & Reduce $\mathrm{CO}_{2}$ emissions from farmstead structures \\
\hline & & Reduce $\mathrm{N}_{2} \mathrm{O}$ emissions: \\
\hline & & By greater nutrient uptake through plant diversity \\
\hline & & By reduced $\mathrm{N}$ fertilizer application in tree component \\
\hline & & Enhance forage quality, thereby reducing $\mathrm{CH}_{4}$ \\
\hline \multicolumn{3}{|l|}{ Adaptation } \\
\hline \multirow{7}{*}{$\begin{array}{l}\text { Actions to reduce or eliminate the } \\
\text { negative effects of climate change or } \\
\text { take advantage of the positive effects }\end{array}$} & \multirow[t]{6}{*}{$\begin{array}{l}\text { Reduce threats and enhance } \\
\text { resilience }\end{array}$} & $\begin{array}{l}\text { Alter microclimate to reduce impact of extreme } \\
\text { weather events on crop production }\end{array}$ \\
\hline & & Alter microclimate to maintain quality and quantity of forage production \\
\hline & & Alter microclimate to reduce livestock stress \\
\hline & & $\begin{array}{l}\text { Provide greater habitat diversity to support organisms } \\
\text { (e.g., native pollinators, beneficial insects) }\end{array}$ \\
\hline & & $\begin{array}{l}\text { Provide greater structural and functional diversity to maintain } \\
\text { and protect natural resource services }\end{array}$ \\
\hline & & $\begin{array}{l}\text { Create diversified production opportunities to reduce risk } \\
\text { under fluctuating climate }\end{array}$ \\
\hline & $\begin{array}{l}\text { Allow species to migrate to } \\
\text { more favorable conditions }\end{array}$ & Provide travel corridors for species migration \\
\hline
\end{tabular}

\section{Figure 2}

Agroforestry has the potential to affect numerous production and ecosystem services that will be impacted by climate change. The landscape setting where the agroforestry practice is placed and how the practice is designed and managed will determine the types and magnitudes of the functions obtained. (Adapted from Bentrup 2008)

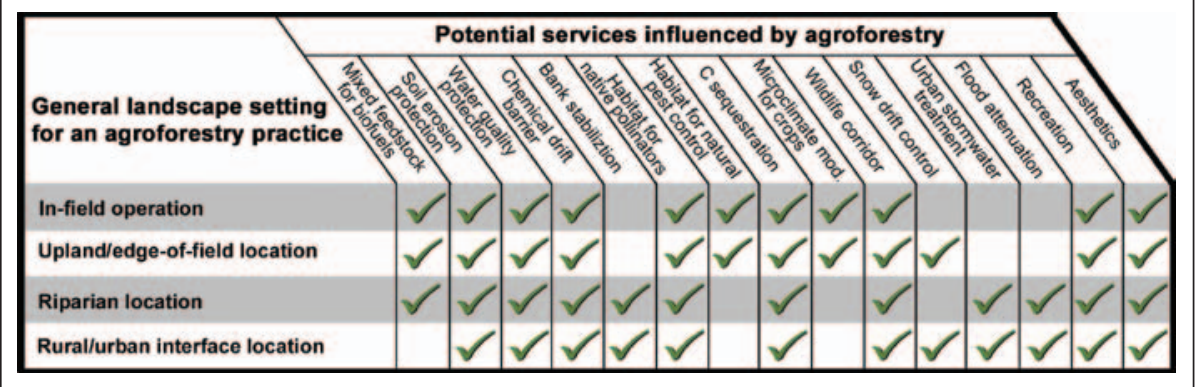

is not easy due to lack of inclusion in any national resource inventory (Perry et al. 2005) and agroforestry-specific tools. Compared to forests, agroforestry plantings have a more open environment, resulting in trees with greater branch production and greater specific gravity (Zhou et al. 2011). These differences indicate that use of existing forest-derived equations may not accurately estimate woody biomass C. Ongoing work in the United States and Canada is providing the basis for determining if existing forest-derived equations for North American trees can be adjusted for better estimation of this $\mathrm{C}$ in agroforestry-generated woody biomass, as well as developing equations for multiplestemmed tree species (Zhou et al. 2007) and shrub species that contribute to this $\mathrm{C}$ stock in agroforestry plantings.

Soil C stocks have been demonstrated to generally be larger in agroforestry systems compared to conventional cropping systems (Kumar and Nair 2011). However, the high variability, measurement expense, and several other factors related to soil C sampling in agroforestry systems make it difficult to estimate and/or model the accrual of new $\mathrm{C}$ with any level of accuracy (Nair 2011). This high variability is 
due to agroforestry's integrated nature that creates greater belowground complexity, as well as the soil $\mathrm{C}$ being derived from both internal and external sources (Sauer et al. 2007). Net accrual of C in soils using C-sequestering activities generally does not continue for many years. Soil organic C (SOC) levels are assumed to stabilize at a new steady state after 20 years (IPCC 2006). Soils under agroforests may accumulate $\mathrm{C}$ beyond this period. Sauer et al. (2007) reported significantly greater SOC in the top $15 \mathrm{~cm}$ (6 in) of soil beneath a 35-year-old windbreak in Nebraska, as compared to adjacent cropped fields. Stable C isotope analysis at this site indicated that tree-derived SOC contributed $54 \%$ of the SOC beneath the trees $(1.73$ $\pm 0.16 \mathrm{~kg} \mathrm{C} \mathrm{m}{ }^{-2}\left(0.35 \pm 0.03 \mathrm{lb} \mathrm{C} \mathrm{ft}^{-2}\right)$, with a mean residence time of 45 years (Hernandez-Ramirez et al. 2011). The observed increase in SOC represents an annual accrual of $10.6 \mathrm{~g} \mathrm{~m}^{-2} \mathrm{y}^{-1}(0.002 \mathrm{lb}$ $\left.\mathrm{ft}^{-2} \mathrm{yr}^{-1}\right)$. Minimized site disturbance and the increased diversity of plant species in windbreaks are credited with reducing C losses and increasing stability of SOC stocks. Along with the GHG mitigation value, increasing SOC is associated with enhanced $\mathrm{C}$ and nutrient cycling, vigorous soil fauna, optimal soil structure, and improved soil water regimes (Doran et al. 1994).

Brandle et al. (1992) demonstrated that a major $\mathrm{C}$ advantage of using windbreaks is the indirect benefits that can potentially be quite substantial. Based on a 2 million ha $(\sim 5$ million ac) windbreak planting program, they estimated that over $22 \mathrm{Tg}$ (24 million $\mathrm{tn}$ ) of $\mathrm{C}$ would be sequestered, and diesel fuel consumption would be reduced by approximately 1,240 million L (328 million gal). Additional fuel saving could be realized from farmstead windbreaks. Given the potential size of indirect C contributions from agroforestry plantings, more work is definitely warranted to help guide accounting efforts. Both our growing understanding of $\mathrm{C}$ cycling within agroforestry systems, as well as our knowledge gaps, will need to be addressed to enable accurate and full $\mathrm{C}$ accounting of agroforestry's contribution (Kumar and Nair 2011).
Nitrous Oxide and Methane. Impacts on nitrous oxide $\left(\mathrm{N}_{2} \mathrm{O}\right)$ and methane $\left(\mathrm{CH}_{4}\right)$ emissions in agroforestry systems also need to be considered. Studies on these GHGs in agroforestry systems are limited. Agroforestry includes many agricultural activities that affect emissions of these GHGs (e.g., fertilization, liming, tillage, and livestock management) and are purposely designed for interactions, including shifts in these management activities, that theoretically could be beneficially managed.

Integrating agroforestry into agricultural operations reduces $\mathrm{N}_{2} \mathrm{O}$ emissions by eliminating nitrogen $(\mathrm{N})$ application on the part occupied by trees. Additionally, emissions may be further reduced through tree uptake of excess N (Allen et al. 2004; Bergeron et al. 2011). Referred to as the safety-net feature of agroforestry, tree roots have the potential to take up excess $\mathrm{N}$ in time and in space that would otherwise be available for $\mathrm{N}_{2} \mathrm{O}$ emissions on- or off-site. Measurements made in several riparian forest buffers (7- to 17-year-old) in Iowa indicated that the lower $\mathrm{N}_{2} \mathrm{O}$ emissions observed in the buffers compared to adjacent crop fields were likely due to both mechanisms - the elimination of $\mathrm{N}$ application in the buffer, as well as greater $\mathrm{N}$ uptake by the trees (Dong-Gill 2008). These functions working in an alley-cropping system compared to sole-cropping plots could lead to reductions in $\mathrm{N}_{2} \mathrm{O}$ emissions of about $0.7 \mathrm{~kg} \mathrm{ha}^{-1} \mathrm{y}^{-1}(0.6 \mathrm{lb}$ $\mathrm{ac}^{-1} \mathrm{yr}^{-1}$ ) (Thevathesan and Gordon 2004).

Even less is known about $\mathrm{CH}_{4}$ emissions in temperate agroforestry. Dong-Gill et al. (2010) did not detect any differences in $\mathrm{CH}_{4}$ emissions between riparian forest buffers and adjacent croplands in Iowa. This may reflect the high level of hydrologic decoupling in the widely tiled landscapes of the Upper Midwest region, as well as suppression of $\mathrm{CH}_{4}$ oxidation found in agricultural systems (Suwanwaree and Robertson 2005).

Results from (Allen et al. 2009) and others (Eckard et al. 2010) indicate that silvopasture may offer several options for reducing $\mathrm{CH}_{4}$ and $\mathrm{N}_{2} \mathrm{O}$ emissions. The integration of plant components in silvopasture should result in diminished $\mathrm{N}_{2} \mathrm{O}$ emissions due to increased nutri- ent efficiency and reduced $\mathrm{N}$ fertilizer inputs. Forage quantity and quality can be expected to be affected by the modified microclimate in these systems, which in turn will affect $\mathrm{CH}_{4}$ emissions from livestock. Lin et al. (2001) found that crude protein, acid detergent fiber, and total crude protein levels were altered depending on forage species and levels of shading, with some species having increased quality under shade. Agroforestry practices offer many opportunities to increase $\mathrm{C}$ sequestration, potentially reduce other GHGs, and help maintain production within whole-farm operations.

\section{CLIMATE CHANGE ADAPTATION}

Adaptation by Agroforestry. Despite its small size, agroforestry can add a high level of diversity within agricultural lands and, with it, an increased capacity for supporting numerous ecological and production services that impart resiliency to CC impacts (table 2 and figure 2) (Verchot et al. 2007). From a landowner's perspective, the most valued services would be those that can dampen the negative effects of CC and weather extremes while augmenting the positive benefits provided by tree-based systems. CC risk management is difficult in annual-only systems due to the increasing uncertainty and volatility of interannual variability in rainfall and temperatures. The mixing of woody plants into crop, forage, and livestock operations provides greater resiliency to this interannual variability through crop diversification produced seasonally, as well as through increased resource-use efficiency (Olson et al. 2000). Deep-rooted trees allow better access to nutrients and water during droughts and, when appropriately integrated into annual cropping or forage systems, may extract from a different pool of resources and/or from resources that would otherwise be lost from the system (van Noordwijk et al. 1996). Agroforestry increases soil porosity, reduces runoff, and increases soil cover, which can improve water infiltration and retention in the soil profile thereby reducing moisture stress in low rainfall years (Jose et al. 2009). During periods of excessive soil moisture, treebased systems can maintain aerated soil conditions by pumping out excess water 
more rapidly than other production systems, and when flooding eliminates an herbaceous crop for a season, the woody component can often survive and offer an economic return (Dimitriou et al. 2009).

Agroforestry practices are used to alter microclimates to produce more favorable conditions for crop, forage, and livestock production, and empirical results suggest these agroforestry-induced conditions could be critical in providing extra resiliency to shifting temperature and moisture regimes. Field studies have shown that air and soil temperatures too cold or too warm for forage growth can be favorably modified by trees in silvopasture systems to create an extended production period (Feldhake 2002; Moreno et al. 2007). Using a process-based model, Easterling et al. (1997) showed that windbreaks would increase dryland maize yields in Nebraska above corresponding unsheltered yields for most levels of predicted climate change.

Along with the impacts of weather extremes on production, increasing carbon dioxide $\left(\mathrm{CO}_{2}\right)$ may reduce the ability of grazing lands to supply adequate livestock feed (USGCRP 2009). Morgan et al. (2004) found that higher levels of $\mathrm{CO}_{2}$ increased forage productivity but reduced forage quality because of the effects on plant $\mathrm{N}$ and protein content. The shading component in silvopasture systems, however, has been shown to improve forage quality by increasing protein content while reducing fiber (Kallenbach et al. 2006), which when combined with creating more favorable microclimate conditions could potentially result in higher forage quantity and quality than opengrazing lands during heat stress events.

With warmer temperatures, insect pests and plant diseases are expected to increase due to range expansion, higher winter survival, and increased number of generations per season (USGCRP 2009). Enhancing opportunities for biological pest control will become increasingly important and could be accomplished through agroforestry (Dix et al. 1995). For example, alfalfa intercropped with walnut supported twice as many predators and parasitic hymenoptera and half as many herbivores as did alfalfa alone (Stamps et al. 2002). Stamps and Linit (1997) reported that the greater niche diversity of agroforestry may support greater numbers and/or diversity of natural enemy populations than even polycultural systems of annual crops.

Increased heat, disease, and weather extremes are likely to reduce livestock productivity, and studies show that the negative effects of hotter summers will outweigh the positive effects of warmer winters (USGCRP 2009). By providing shade, silvopasture can reduce the energy expended for thermoregulation, leading to higher feed conversion and weight gain. Mitlöhner et al. (2001) found that cattle provided with shade reached their target body weight 20 days earlier than those without shade.

Climate change is expected to result in more erratic precipitation patterns that will ultimately lead to higher soil erosion rates. Where rainfall amounts increase, erosion and runoff will increase at an even greater rate: the ratio of erosion increase to annual rainfall increase is on the order of 1.7 (Nearing et al. 2004). Where annual rainfall decreases, system feedbacks related to decreased biomass production and soil drying could lead to greater susceptibility of the soil to erode. Modelling results indicated a $2^{\circ} \mathrm{C}$ increase in annual temperature could increase wind erosion by $15 \%$ to 18\% (Lee et al. 1996). Windbreaks, alleycropping systems, and riparian buffers are typically designed for reducing wind and water erosion (Garrett 2009).

Agroforestry systems can offer greater economic stability and reduced risk under CC by creating more diversified enterprises with greater income distribution over time. Like alley cropping, a silvopasture system mitigates risks associated with climate variability and fluctuating prices by providing short-term (forage and/or livestock) and long-term (timber) income sources (Cubbage et al. 2012).

Conserving biological diversity under shifting climates is a global priority (Korn et al. 2003). Agroforestry can play three major roles in supporting this priority: (1) providing habitat that offers a range of microclimate and resource refugia; (2) increasing landscape connectivity for species to migrate as climate changes; and (3) providing other ecosystem services, such as erosion control and water quality protec- tion, that prevent the degradation and loss of surrounding habitat. Realizing these beneficial adaption services will require additional work to develop improved combinations and arrangements of species that better maximize facilitative interactions, while minimizing the competitive interactions between crop and trees (Jose et al. 2009).

Adaptation of Agroforestry. Despite the positive $\mathrm{CC}$ adaptation services that agroforestry can provide, these systems will likely be negatively impacted by the same forces. Plant stress, as well as shifts in woody plant disease, pest and natural enemy dynamics created by weather extremes, and the longer-term predicted shifts in climate, will play a dominant role in the persistence and performance of all agroforestry plants, herbaceous or woody (Fuhrer 2003; Allen et al. 2010). This is of particular concern with agroforestry as these practices require a long time to become established and fully functional. Losing one's investment due to a stress and/or pest outbreak would be devastating. With limited research on CC-adapted plant materials and, more importantly, due to the longevity of the woody component, one is left with using diversity as a key principle in developing CC-adapted agroforestry plantings: in essence, selecting a variety of plants that will thrive under the many conditions created by shifting weather and climate change. Breeding programs can also expand selection options, such as the marker-assisted poplar breeding program in Canada that is utilizing the AgCanBaP collection (Soolanayakanahally 2010) to generate woody biomass feedstocks with high resource use efficiencies for present and future climates. Climate modeling results are indicating major shifts in tree species distribution (Iverson and Prasad 1998). Projecting out which agroforestry species that may be more suited to future conditions will need to become part of the CC-integrated planning and design process.

\section{RETHINKING AGROFORESTRY}

Although agroforestry practices have been traditionally implemented to achieve a few major functions, by rethinking these practices, we can capitalize on the poten- 
tial synergies among CC, production, and ecosystems services. Riparian forest buffers offer a perfect example for retooling an existing practice into an innovative system with additional positive feedback loops (figure 3). Widening the zones and selecting appropriate species can create opportunities for harvesting biomass or bioproducts. The additional width offers extra water quality protection under increasing intense rainfall events, with the harvest of marketable materials helping to offset lost opportunity costs of land taken out of regular production. Harvesting also provides the added services of removing nutrients from the site and keeping the woody portion in an earlier successional stage; both activities promote greater regrowth and nutrient uptake rates that in turn could further enhance water quality services, as well as potentially reduce $\mathrm{N}_{2} \mathrm{O}$ emissions. If pyrolysis is used to convert biomass to energy, the resulting C-rich biochar could be returned to adjacent fields as an amendment for improving soil quality and yields (Stavi and Lal 2012) and potentially reducing $\mathrm{N}_{2} \mathrm{O}$ emissions (Taghizadeh-Toosi et al. 2011). Through species selection, increased width, and other design considerations, the riparian forest buffer can enhance adaptation to $\mathrm{CC}$ by providing habitat for beneficial insects and birds, stream temperature modification, and streambank stabilization. When a landscape system of riparian buffers is created, landscape-level benefits, like flood attenuation and corridors for wildlife movement, can also then be realized.

By ignoring the imaginary limitations of existing practices, we can invent new tree-based systems that can better respond to dynamic changes in the environment and market place. For example, waterbreaks offer a novel agroforestry system for addressing the increase in flooding intensity and frequency and the resulting degradation of agricultural lands by providing a series of strategically placed buffers in the floodplain that can reduce the impacts from flood events (figure 4). The placement and use of waterbreaks are intended to moderate water flows similar to the way windbreaks moderate wind flows (Wallace et al. 2000). During nonflooded conditions, waterbreaks

\section{Figure 3}

Riparian forest buffers may potentially provide greenhouse gas mitigation by reducing nitrous oxide $\left(\mathrm{N}_{2} \mathrm{O}\right)$ emissions, enhancing methane $\left(\mathrm{CH}_{3}\right)$ uptake, and sequestering carbon, as well as contributing to bioenergy. By strategically locating and redesigning this practice, additional services, including climate change adaptation services, can also be derived.

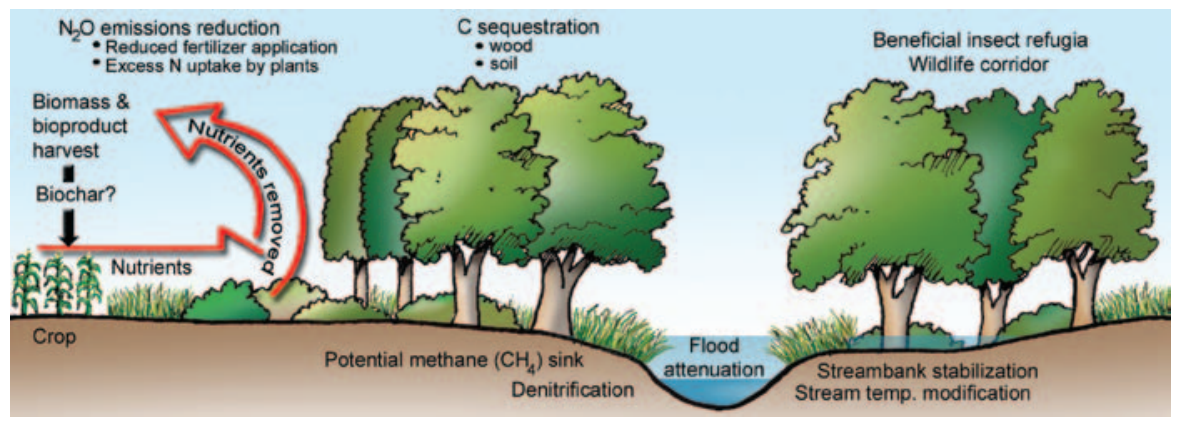

\section{Figure 4}

By reconsidering traditional agroforestry practices, new approaches, such as waterbreaks, can be designed to meet the evolving challenges of climate change.
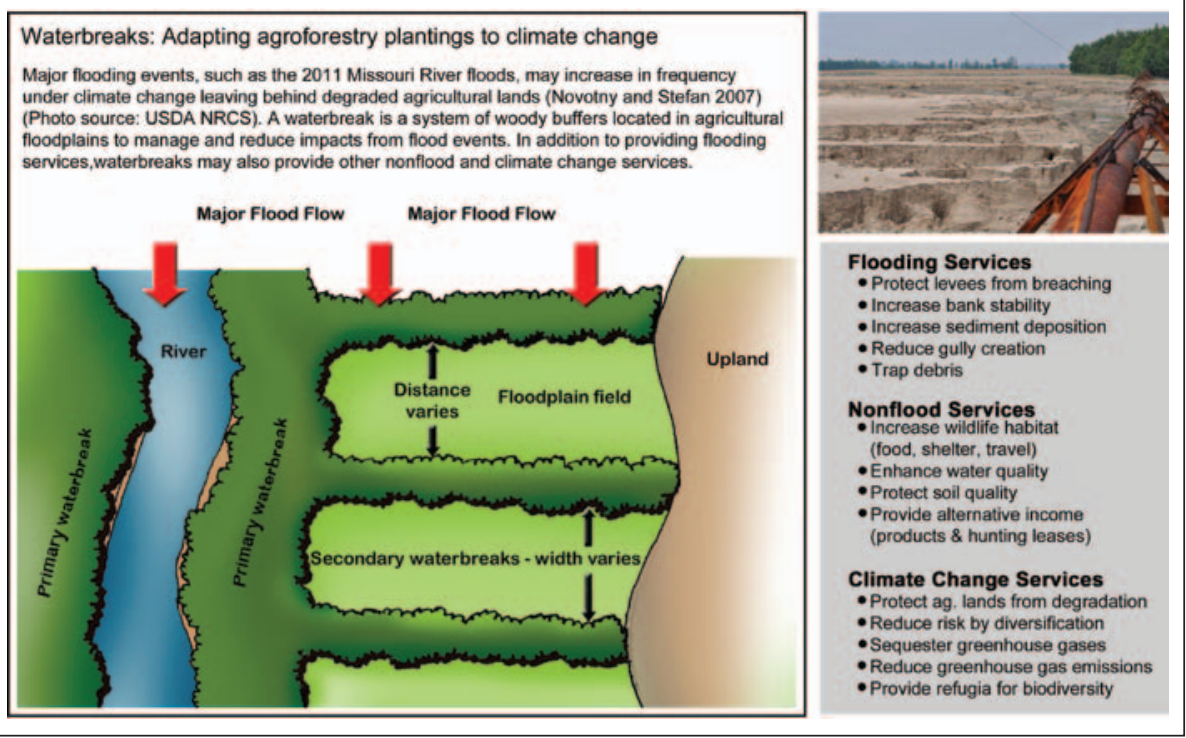

can provide critical wildlife connections between upland and riparian areas and improve water quality by trapping sediment and filtering chemicals from runoff, while providing opportunities for alternative income through hunting fees and harvesting products such as timber, nuts, and other nontimber forest products. Rethinking agroforestry will help link the multiple objectives of food, feed, fiber, energy, and ecosystem services on these lands under CC, but much work remains to get all the right parts together (Schoeneberger et al. 2008; Holzmueller and Jose 2012).

\section{BRANCHING OUT}

Agroforestry is one of several CC M\&A tools that will be needed for agricultural lands under the uncertainty of CC. In North America, agroforestry is gaining momentum, as illustrated by (1) release of the USDA Agroforestry Strategic Framework (2011-2016) (http://www. usda.gov/documents/AFStratFrame FINAL-lr_6-3-11.pdf) and establishment of the Agroforestry Executive Steering Committee with seven USDA member agencies, (2) release of the Memorandum of Understanding between Canada and the United States to advance collaboration between the USDA National Agroforestry 
Center and the Agriculture and AgriFood Canada Agroforestry Development Centre, and (3) involvement of both countries and centers in the Global Research Alliance on Agricultural Greenhouse Gases, an international group supporting development and transfer of new CC M\&A practices available to farmers worldwide (http://www.globalresearchalliance. org/about-us/).

While we have identified several promising avenues for CC M\&A through agroforestry, it should be recognized that our understanding is limited. The sparse research conducted to-date has predominantly focused on single management activity impacts within a practice, such as $\mathrm{C}$ sequestered in woody biomass. Dynamics in a system as spatially and temporally complex as agroforestry require additional research and technology investment so that we can verify and reliably predict responses under the variety of field conditions that agroforestry can be placed in and the variety of management activities and species that can be used. However, it is this very complexity in agroforestry that provides its potential for meeting GHG objectives and providing the resiliency needed for attaining production and the other ecosystem service goals demanded from these lands.

Regarding temperate agroforestry, Jose and Gordon (2008) have stated that we need to "1) Recognize the limited understanding; 2) Develop better information; and 3) Develop decision-support tools and models." In short, while much work remains regarding researching agroforestry's CC M\&A potential for North American agriculture, we also need to be using the science at-hand to assist today's decision making. Tools, such as the COMET-VR 2 from the USDA and HOLOS from the Agriculture and Agri-Food Canada, that estimate wholefarm GHG emissions, are beginning to include agroforestry within the accounting framework (table 1). The development of standardized GHG measurements (e.g., USDA Agricultural Research Service GRACEnet sampling protocols) for use in agroforestry studies that will help in developing the accuracy of the models used in these tools has also been initiated. Many different CC-integrated tools will be needed to ensure food security and other essential human enterprises in North America and elsewhere. Agroforestry is one of these promising tools for helping to build that climate-smart agriculture.

\section{REFERENCES}

Allen, S.A., S. Jose, P.K.R. Nair, B.J. Brecke, P. NkediKizza, and C.L. Ramsey. 2004. Safety-net role of tree roots: evidence from a pecan (Carya illinoensis K. Koch)-cotton (Gossypium hirsutum L.) alley cropping system in the southern United States. Forest Ecology and Management 192:395-407.

Allen, D.E., D.S. Mendham, B. Singh, A. Cowie, W. Wang, R.C. Dalal, and R.J. Raison. 2009. Nitrous oxide and methane emissions from soils are reduced following afforestation of pasture lands in three contrasting climatic zones. Australian Journal of Soil Research 47:443-458.

Allen, C.D., A.K. Macalady, H. Chenchouni, D. Bachelet, N. McDowell, M. Vennetier, T. Kitzberger,A. Rigling, D.D. Breshears, E.H. Hogg, P. Gonzalez, R. Fensham, Z. Zhang, J. Castro, N. Demidova, J.H. Lim, G. Allard, S.W. Running, A. Semerci, and N. Cobb. 2010. A global overview of drought and heat-induced tree mortality reveals emerging climate change risks for forests. Forest Ecology and Management 259:660-684.

Bentrup, G. 2008. Conservation Buffers: Design Guidelines for Buffers, Corridors, and Greenways. General Technical Report SRS-109. Asheville, NC: USDA Forest Service, Southern Research Station.

Bergeron, M., S. Lacombe, R.L. Bradley, J. Whalen, A. Cogliastro, M-F., Jutras, and P.Arp. 2011. Reduced soil nutrient leaching following the establishment of tree-based intercropping systems in eastern Canada. Agroforestry Systems 83:321-330.

Brandle, J.R., Wardle, T.D., and Bratton, G.F. 1992. Opportunities to increase tree plantings in shelterbelts and the potential impacts on carbon storage and conservation. In Forests and Global Change, Vol. 1: Ch. 9, eds. R.N. Sampson and D. Hairs, 157-175. Washington, DC: American Forests.

CAST (Council for Agricultural Science and Technology). 2011. Carbon sequestration and greenhouse gas fluxes in agriculture: Challenges and opportunities. CAST Task Force Report 142. Ames, IA: Council for Agricultural Science and Technology.

Cubbage, F., V. Glenn, J.P. Mueller, D. Robinson, R. Myers, J-M. Luginbuhl, and R. Myers. 2012. Early tree growth, crop yields, and estimated returns for an agroforestry trial in Goldsboro, NC. Agroforestry Systems: DOI: 10.1007/ s10457-012-9481-0.
Delgado, J.A., P.M. Groffman, M.A. Nearing, T. Goddard, D. Reicosky, R. Lal, N.R. Kitchen, C.W. Rice, D. Towery, and P. Salon. 2011. Conservation practices to mitigate and adapt to climate change. Journal of Soil and Water Conservation 66(4):118A-129A.

Dimitriou, I., G. Busch, S. Jacobs, P. Schmidt-Walter, and N. Lamersdorf. 2009. A review of the impacts of short rotation coppice cultivation on water issues. Landbauforschung Volkenrode 59:197-206.

Dix, M.E., R.J. Johnson, M.O. Harrell, R.M. Case, R.J. Wright, L. Hodges, J.R. Brandle, M.M. Schoeneberger, N.J. Sunderman, R.L. Fitzmaurice, L.J. Young, and K. G. Hubbard. 1995. Influences of trees on abundance of natural enemies of insect pests: a review. Agroforestry Systems 29: 303-311.

Dong-Gill, K. 2008. Nitrous Oxide and Methane Fluxes in Riparian Buffers and Adjacent Crop Fields. PhD dissertation, Iowa State University, DAI-B 69/08.

Dong-Gill, K., T. Isenhart, T.B. Parkin, R.C. Schultz, and T.E. Loynachan. 2010. Methane flux in cropland and adjacent riparian buffers with different vegetation covers. Journal of Environmental Quality 39:97-105.

Doran, J.W., D.C. Coleman, D.F. Bezdicek, and B.A. Stewart, eds. 1994. Defining Soil Quality for a Sustainable Environment, Madison, WI: Soil Science Society of America, Inc.

Eagle, A., L. Olander, L.Henry, K. Haugen-Kozyra, N. Millar, and G.P. Robertson. 2012. Greenhouse Gas Mitigation Potential of Agricultural Land Management in the United States: A Synthesis of the Literature. Report NIR 10-04, 3rd ed., Durham, NC: Nicholas Institute for Environmental Policy Solutions, Duke University.

Eckard, R.J., C. Grainger, and C.A.M. de Klein. 2010. Options for the abatement of methane and nitrous oxide from ruminant production: A review. Livestock Science 130:47-56.

Easterling, W.E., C.J. Hays, M.M. Easterling, and J.R. Brandle. 1997. Modelling the effect of shelterbelts on maize productivity under climate change: an application of the EPIC model. Agriculture, Ecosystems and Environment 61:163-176.

Feldhake, C.M. 2002. Forage frost protection potential of conifer silvopasture. Agricultural and Forest Meteorology 112:123-130.

Field, C.B., L.D. Mortsch, M. Brklacich, D.L. Forbes, P. Kovacs, J.A. Patz, S.W. Running, and M.J. Scott. 2007. North America. Climate Change 2007: Impacts, Adaptation and Vulnerability. In Contribution of Working Group II to the Fourth Assessment Report of the Intergovernmental Panel on Climate Change, eds. M.L. Parry 
et al., 617-652. Cambridge UK: Cambridge University Press.

Fuhrer, J. 2003. Agroecosystem responses to combinations of elevated $\mathrm{CO}_{2}$, ozone, and global climate change. Agriculture, Ecosystems and Environment 97:1-20.

Garrett, H.E., ed. 2009. North American Agroforestry: An Integrated Science and Practice, 2nd ed., Madison, WI: American Society of Agronomy, Inc.

Hernandez-Ramirez, G.,T.J. Sauer, C.A. Cambardella, J.R. Brandle, and D.E. James. 2011. Carbon sources and dynamics in afforested and cultivated Corn Belt soils. Soil Science Society of America Journal 75:216-225.

Holzmueller, E.J. and S. Jose. 2012. Biomass production for biofuels using agroforestry: potential for the North Central Region of the United States. Agroforestry Systems: DOI 10.1007/ s10457-012-9502-z.

IPCC (Intergovernmental Panel on Climate Change). 2006. 2006 IPCC Guidelines for National Greenhouse Gas Inventories, Vol. 4. 2006 IPCC Guidelines for National Greenhouse Gas Inventories, Volume 4: Agriculture, Forestry and Other Land Use. Prepared by the National Greenhouse Gas Inventories Programme, eds. Eggleston H.S., Buendia L., Miwa K., Ngara T. and Tanabe K., Published: IGES, Japan. http:// www.ipcc-nggip.iges.or.jp/public/2006gl/vol4 html

Iverson, L.R., and A.M. Prasad. 1998. Predicting abundance of 80 tree species following climate change in eastern United States. Ecological Monographs 68:465-485.

Jose, S., and A.M. Gordon. 2008. Ecological knowledge and agroforestry design: an introduction. In Toward Agroforestry Design. Vol. 4: Advances in Agroforestry, eds. S. Jose and A.M. Gordon, 3-9. New York: Springer.

Jose, S., E.J. Holzmueller, and A.R. Gillespie. 2009. Tree-crop interactions in temperate agroforestry. In North American Agroforestry: An Integrated Science and Practice. 2nd ed., ed. H.E. Garrett, 57-73. Madison, WI: American Society of Agronomy, Inc.

Kallenbach, R.L., M.S. Kerley, and G.J. BishopHurley. 2006. Cumulative forage production, forage quality and livestock performance from an annual ryegrass and cereal rye mixture in a pine-walnut silvopasture. Agroforestry Systems 66:43-53.

Korn, H., P. Ntayombya, O. Berghall, J. Cotter, R. Lamb, G. Ruark, and I.Thompson .2003. Climate change mitigation and adaptation options: Links to, and impacts, on biodiversity. In Interlinkages between biological diversity and climate change: Advice on the integration of biodiversity considerations into the implementation of the United Nations Framework Convention on Climate Change and its Kyoto protocol, pp. 48-87. CBD Technical Series no. 10. Montreal, Canada: Secretariat of the Convention on Biological Diversity. http://www.biodiv.org/doc/publications/cbd-ts-10.pdf.

Kumar, B.M., and P.K.R. Nair, eds. 2011. Carbon Sequestration Potential of Agroforestry Systems: Opportunities and Challenges.Vol. 8:Advances in Agroforestry. New York: Springer.

Lee, J.J., D.L. Phillips, and R.F. Dodson. 1996. Sensitivity of the US Corn Belt to climate change and elevated $\mathrm{CO}_{2}$ : II. Soil erosion and organic carbon. Agricultural Systems 52:503-521.

Lin, C.H., R.L. McGraw, M.F. George, and H.E Garrett. 2001. Nutritive quality and morphological development under partial shade of some forage species with agroforestry potential Agroforestry Systems 53:269-281.

Mitlöhner, F.M., J.L. Morrow, J.W.Dailey, S.C.Wilson, M.L. Galyean, M.F. Miller, and J.J. McGlone. 2001. Journal of Animal Science 79:2327-2335.

Moreno, M.G., J.J. Obrador, E. Garcia, E. Cubera, M.J. Montero, F. Pulido, and C. Dupraz. 2007. Driving competitive and facilitative interactions in oak dehasa through management practices. Agroforestry Systems 70:25-40.

Morgan, J.A., A.R. Mosier, D.G. Milchunas, D.R. LeCain, J.A. Nelson, and W. J. Parton. 2004. $\mathrm{CO}_{2}$ enhances productivity, alters species composition, and reduces digestibility of shortgrass steppe vegetation. Ecological Applications 14:208-219.

Morgan, J.A., R.F. Follett, L.H. Allen, S. Del Grosso, J.D. Derner, F. Dijkstra, A. Franzluebbers, R. Fry, K. Paustian, and M.M. Schoeneberger. 2010. Carbon sequestration in agricultural lands of the United States. Journal of Soil and Water Conservation 65:6A-13A.

Nair, P.K.R. 2011. Methodological challenges in estimating carbon sequestration potential of agroforestry systems. In Carbon Sequestration Potential of Agroforestry Systems: Opportunities and Challenges. Vol. 8: Advances in Agroforestry, eds. B.M. Kumar and P.K.R. Nair, 3-16. New York: Springer.

Nearing, M.A., F.F. Pruski, and M.R. O’Neal. 2004. Expected climate change impacts on soil erosion rates: A review. Journal of Soil and Water Conservation 59 (1):43-50.

Novotny, E.V., and H.G. Stefan. 2007. Stream flow in Minnesota: Indicator of climate change. Journal of Hydrology 334:319-333.
Olson, R.K., M.M. Schoeneberger, and S.G. Aschmann. 2000. An ecological foundation for temperate agroforestry. In North American Agroforestry: An Integrated Science and Practice, eds. H.E. Garrett, W.J. Rietveld, and R.F. Fisher, 31-62. Madison, WI: American Society of Agronomy, Inc.

Peichl, M., N.V. Thevathesan, A.M. Gordon, J.Huss, and R.A.Abohassan. 2006. Carbon sequestration potentials in temperate tree-based intercropping systems, southern Ontario, Canada. Agroforestry Systems 66:243-257.

Perry, C.H., C.W.Woodall, and M.M. Schoeneberger. 2005. Inventorying trees in agricultural landscapes: toward an accounting of working trees. In Moving Agroforestry into the Mainstream. Proceedings of the 9th North American Agroforestry Conference, Rochester, MN, June 12-15, 2005. Department of Forest Resources, eds. K. N Brooks and P.F. Ffolliott. University of Minnesota, St. Paul, Minnesota. http://www.cinram.umn.edu/afta2005/pdf/Perry.PDF.

Sauer, T.J., C.A. Cambardella, and J.R. Brandle. 2007. Soil carbon and tree litter dynamics in a red cedar-scotch pine shelterbelt. Agroforestry Systems 71:163-174.

Sauer, T.J. 2010. The Prairie States Forestry Project as a model for an effective global climate change mitigation project. In Management, Practices and Environmental Impact, ed. L. R. Kellimore, 479-482. Hauppauge, NY: Agroforestry Nova Publishers.

Schoeneberger, M.M., G. Bentrup, D. Current, B. Wight, and T. Simpson. 2008. Building bigger better buffers for bioenergy. Water Resources Impact 10:22-26.

Schoeneberger, M.M. 2009. Agroforestry: working trees for sequestering carbon on agricultural lands. Agroforestry Systems 75:27-37.

Soolanayakanahally, R. 2010. Latitudinal Gradients in Adaptive Traits of Populus. PhD dissertation, University of British Columbia.

Stamps, W.T., and M.J. Linit. 1997. Plant diversity and arthropod communities: implications for temperate agroforestry. Agroforestry Systems 39:73-89.

Stamps, W.T., T.W. Woods, M.J. Linit, and H.E. Garrett. 2002. Arthropod diversity in alley cropped black walnut (Juglans nigra L.) stands in eastern Missouri, USA. Agroforestry Systems 56:167-175

Stavi, I., and R. Lal. 2012. Agroforestry and biochar to offset climate change: A review. Agronomy for Sustainable Development: DOI: 10.1007/ s13593-012-0081-1.

Suwanwaree, P., and G.P. Robertson. 2005. Methane oxidation in forest, successional, and no-till 
agricultural ecosystems: effects of nitrogen and disturbance. Soil Science Society of America Journal 69:1722-1729.

SWCS (Soil and Water Conservation Society). 2011. Position Statement on Climate Change and Soil and Water Conservation. Ankeny, IA: Soil and Water Conservation Society. http://www.swcs. org/documents/filelibrary/climate/SWCS_ Climate_Press_Release_C7A5421A213D7.pdf.

SWCS. 2012. Science and Policy Committee PowerPoints on the Climate Change Position Statement and Task Force Report. Ankeny, IA: Soil and Water Conservation Society. http:// www.swcs.org/en/policy.

Taghizadeh-Toosi, A., T.J. Clough, L.M. Condron, R.R. Sherlock, C.R.Anderson, and R.A. Craigie. 2011. Biochar incorporation into pasture soil suppresses in situ nitrous oxide emissions from ruminant urine patches. Journal of Environmental Quality 40:468-476.

Thevathesan, N.V., and A.M. Gordon. 2004. Ecology of tree intercropping systems in the North temperate region: Experiences from southern Ontario, Canada. Agroforestry Systems 61:257-268.

Tsonkova, P., C. Bohm, A. Quinkenstein, and D. Freese. 2012. Ecological benefits provided by alley cropping systems for production of woody biomass in the temperate region: a review. Agroforestry Systems 85:133-152.

Tufekcioglu, A., J.W. Reich, T.M. Isenhart, and R.C. Schultz. 2003. Biomass, carbon and nitrogen dynamics of multi-species riparian buffers within an agricultural watershed in Iowa, USA. Agroforestry Systems 57:187-198.

Udawatta, R.P., and S. Jose. 2011. Carbon sequestration potential of agroforestry practices in temperate North America. In Carbon Sequestration Potential of Agroforestry Systems: Opportunities and Challenges.Vol. 8:Advances in Agroforestry, eds. B.M. Kumar and P.K.R. Nair, 17-42. New York: Springer.

USGCRP (US Global Change Research Program). 2009. Global climate change impacts in the US. Washington, DC: US Global Change Research Program. http://www.globalchange.gov/publi cations/reports/scientific-assessments/ us-impacts.

van Noordwijk, M., G. Lawson, A. Soumare, J.J.R. Groot, and K. Hairiah. 1996. Root distribution of trees and crops: competition and/or complementarity. In Tree-crop interactions: a physiological approach, eds. C.K. Ong and P. Huxley, 319-364. Wallingford, U.K.: CAB International.
Verchot, L.V., M.Van Noordwijk, S. Kandji,T.Tomich, C. Ong, A. Albrecht, J. Mackensen, C. Bantilan, K.V. Anumpama, and C. Palm. 2007. Climate change: linking adaptation and mitigation through agroforestry. Mitigation and Adaption Strategies for Global Change 12:901-918.

Wallace, D.C., W.A. Geyer, and J.P. Dwyer. 2000. Waterbreaks: managed trees for the floodplain. Agroforestry Notes: Special Applications \#4. http://www.unl.edu/nac/agroforestrynotes/ an19sa04.pdf.

Zhou, X.H., J.R. Brandle, M.M. Schoeneberger, T. Awada. 2007. Developing above-ground woody biomass equations for open-grown, multiple-stemmed tree species: Shelterbeltgrown Russian-olive. Ecological Modelling 202:311-323.

Zhou, X.H., J.R. Brandle, T.N. Awada, M.M. Schoeneberger, D.L. Martin, Y. Xin, and Z.H. Tang. 2011. The use of forest-derived specific gravity for the conversion of volume to biomass for open-grown trees on agricultural land. Biomass and Bioenergy 35:1721-1731. 